\title{
Penerapan Model Pembelajaran Talking Stick dan Puzzle Terhadap Life Skill dan Hasil Belajar Mahasiswa Universitas Sulawesi Barat
}

\author{
Nurhikma Ramadhana ${ }^{1 *}$, Muhammad Rizky Prawira ${ }^{2}$, Muhammad Syukri ${ }^{3}$ \\ 1. Prodi Pendidikan Biologi-FKIP, Universitas Sulawesi Barat \\ 2. Prodi Hubungan Internasional, Universitas Sulawesi Barat \\ 3. Prodi Akuakultur, Universitas Sulawesi Barat \\ *e-mail:nurhikma@unsulbar.ac.id
}

\begin{abstract}
Abstrak:
Penelitian ini bertujuan untuk mengetahui life skill dan perbedaan hasil belajar biologi mahasiswa yang dibelajarkan dengan model kooperatif Talking Stick dan mahasiswa yang dibelajarkan dengan model koopertif puzzle. Berdasarkan observasi hingga saat ini hasil belajar biologi masih dianggap rendah. Berdasarkan observasi dikelas A dan C mahasiswa jurusan Pendidikan Biologi, pembelajaran biologi masih pasif dan monoton karena bergantung pada penjelasan dosen. Pola pembelajaran di kelas selama ini sering menggunakan metode ceramah, oleh sebab itu keterlibatan siswa kurang, sehingga pembelajaran menjadi kurang menyenangkan dan siswa kurang aktif dan kreatif dalam menerima materi pembelajaran, selain itu permasalahan yang terjadi dalam proses kegiatan belajar hanya didominasi oleh sebagian kecil mahasiswa, sedang siswa yang lain hanya diam dan tidak paham dengan materi pembelajaran yang mengakibatkan aktivitas proses pembelajaran kurang efektif atau tujuan pembelajaran tidak tercapai. Metode dalam penelitian ini menggunakan treatment yang digunakan untuk mencari pengaruh perlakuan tertentu dalam kondisi yang terkendalikan. Metode ini merupakan bagian dari metode kuantitatif yang mempunyai ciri khas dengan adanya kelompok kontrol dan kelompok eksperimen yang akan berdampak positif terhadap peningkatan life skill dan hasil belajar peserta didik dengan menggunakan model pembelajaran talking stick dan Puzzle.
\end{abstract}

Kata kunci: Hasil Belajar, Model Pembelajaran, Pendidikan Biologi, Puzzle, Talking Stick.

\section{PENDAHULUAN}

Salah satu permasalahan pendidikan yang dihadapi oleh bangsa Indonesia adalah rendahnya mutu pendidikan pada setiap jenjang dan satuan pendidikan, khususnya pendidikan pada perguruan tinggi. Berbagai usaha telah dilakukan untuk meningkatkan mutu pendidikan nasional, antara lain melalui berbagai pelatihan dan peningkatan kompetensi dosen, pengadaan buku dan alat pelajaran, perbaikan sarana dan prasarana pendidikan, serta peningkatan mutu manajemen sekolah. Namun demikian berbagai indikator mutu pendidikan belum menunjukkan peningkatan yang berarti. Banyak pihak yang mempertanyakan apa yang salah dalam penyelenggaraan pendidikan kita. Dari berbagai pengamatan dan analisis, ada banyak faktor yang menyebabkan mutu pendidikan tidak mengalami peningkatan yang bermakna, salah satunya, yaitu lemahnya proses pembelajaran di perguruan tinggi.

Fakta yang dapat kita lihat di perguruan tinggi bahwa proses pembelajaran lebih cenderung didominasi oleh dosen. Kondisi ini menyebabkan sebagian mahasiswa menjadi bosan, bahkan tidak sedikit dari mereka yang justru bermain dalam kelas pada saat pembelajaran sedang berlangsung. 
Untuk mengatasi hal tersebut, dosen seyogyanya mengetahui bagaimana cara mahasiswa belajar dan menguasai berbagai cara membelajarkan mahasiswa, sehingga siswa akan terhindar dari rasa bosan dan tercipta suasana pembelajaran yang aktif, kreatif, efektif dan menyenangkan. Agar tercipta suasana pembelajaran tersebut, seorang dosen perlu melakukan pemilihan model dan metode pembelajaran yang tepat. Pemilihan model pembelajaran yang tepat diharapkan mampu meningkatkan keaktifan mahasiswa dalam proses pembelajaran yang akan berdampak pada pengaruh positif hasil belajar mahasiswa. Salah satu contoh dari model pembelajaran kooperatif, yakni model kooperatif tipe Talking Stick suatu model pembelajaran kelompok dengan bantuan tongkat, kelompok yang memegang tongkat terlebih dahulu wajib menjawab pertanyaan dari guru setelah siswa mempelajari materi pokoknya, selanjutnya kegiatan tersebut diulang terus-menerus sampai semua kelompok mendapat giliran untuk menjawab pertanyaan dari guru.Dalam penerapan model pembelajaran Kooperatif Tipe Talking Stick ini, guru membagi kelas menjadi kelompok-kelompok dengan anggota 5 atau 6 orang yang heterogen. Kelompokdibentuk dengan mempertimbangkan keakraban, persahabatan atau minat, yang dalam topik selanjutnya menyiapkan dan mempersentasekan laporannya kepada seluruh kelas (Trianto, 2007).

Tipe model pembelajaran kooperatif lain yang dapat diterapkan dalam proses pembelajaran biologi di kelas yakni model kooperatif tipe Puzzle Dapatkan permainan teka-teki menyusun potongan-potongan gambar peserta didik atau buatkan sendiri (Abdurrahman 2007).

Berdasarkan latar belakang yang telah dijelaskan di atas, maka penulis bermaksud untuk meneliti perbandingan kedua model pembelajaran tersebut yang dimaksudkan untuk melihat model pembelajaran yang manakah dari kedua model pembelajaran tersebut yang dapat memberikan life skill dan hasil belajar yang lebih baik dalam rangka memberikan pengaruh positif pada life skill dan hasil belajar mahasiswa pendidikan biologi univesitas Sulawesi Barat.

\section{Metode}

Fokus penelitian ini adalah metode kuantitatif yang mempunyai ciri khas dengan adanya kelompok kontrol dan kelompok eksperimen yang akan berdampak positif terhadap peningkatan life skill dan hasil belajar peserta didik dengan menggunakan model pembelajaran talking stick dan Puzzle.

Jenis penelitian adalah eksperimen semu dengan menggunakan analisis statistik deskriptif yang digunakan untuk mendeskripsikan tingkat penguasaan materi oleh mahasiswa yang dapat terlihat dari distribusi nilai hasil belajar mahasiswa pada mata kuliah sistem pencernaan yang diperoleh oleh setiap mahasiswa yang diajar dengan menggunakan model kooperatif tipe Talking stick maupun dengan model kooperatif tipe Puzzle. Hasil analisis yang dilakukan akan membagi siswa ke dalam sejumlah kategori pencapaian hasil belajar. Pedoman pengkategorian hasil belajar biologi mahasiswa yang digunakan dalam penelitian ini adalah (Arikunto, 2005). Populasi pada penelitian ini Mahasiswa angakatan 2018 yang terdiri dari 4 kelas dengan jumlah siswa keseluruhan 80 siswa. Sampel pada penelitian Kelas A berjumlah 20 siswa sebagai kelas eksprimen (pembanding) talking stick Kelas B berjumlah 20 siswa sebagai kelas eksperimen (yang dibandingkan) permainan puzzle. 


\section{Pembahasan}

Hasil analisis statistik yang diperoleh baik secara deskriptif maupun secara inferensial memperlihatkan adanya perbedaan hasil belajar biologi mata kuliah sistem pernapasan mahasiswa kelas A pada konsep sistem pernapasan yang sangat signifikan antara mahasiswa yang dibelajarkan dengan model pembelajaran kooperatif Talking stick dengan mahasiswa yang dibelajarkan dengan menggunakan model kooperatif tipe Puzzle. Dalam hal ini model pembelajaran kooperatif Talking Stick menunjukkan perolehan hasil belajar yang lebih tinggi dari model pembelajaran kooperatif Puzzle. Hal ini dapat kita lihat dari distribusi nilai dan distribusi frekuensi serta persentase hasil belajar mahasiswa dari kedua model pembelajaran tersebut. Dimana perolehan nilai rata-rata untuk mahasiswa yang dibelajarkan dengan model kooperatif Talking Stick, yakni 83,66, dengan standar deviasi 3,92. Nilai standar deviasi tersebut menunjukkan bahwa besarnya nilai simpangan baku yang diperoleh mahasiswa terhadap nilai rata-rata sangat kecil, yang menunjukkan bahwa rentang nilai yang diperoleh mahasiswa sangat kecil (nilai mahasiswa lebih merata). Hal ini secara jelas terlihat dari persentase hasil belajar mahasiswa, yakni; $80 \%$ dikategorikan sangat baik, $20 \%$ dikatgorikan baik, dan $0,00 \%$ untuk kategori cukup, kurang, dan gagal. Sedangkan untuk mahasiswa yang dibelajarkan dengan model kooperatif Puzzle, nilai rata-rata yang diperoleh yakni 80,5 dengan standar deviasi 4,64. Nilai standar deviasi tersebut menunjukkan bahwa besarnya nilai simpangan baku terhadap nilai rata-rata yang diperoleh mahasiswa yang dibelajarkan dengan model puzzle lebih besar dari nilai simpangan baku yang diperoleh mahasiswa yang dibelajarkan dengan model kooperatif Talking Stick, yang menunjukkan bahwa rentang nilai yang diperoleh mahasiswa lebih besar (nilai mahasiswa lebih menyebar). Hal tersebut dapat terlihat dari persentase hasil belajar, yakni; 48,33 \% dikategorikan baik sekali, 51,67\% dikategorikan baik, dan 0,00\% untuk kategori cukup, kurang, dan gagal.

Tingkat keberhasilan suatu proses pembelajaran dipengaruhi oleh banyak faktor. Salah satu faktor penyebab tingginya hasil belajar biologi siswa yang dibelajarkan dengan menggunakan model pembelajaran kooperatif Talking Stick dikarenakan dalam proses pembelajaran mahasiswa diberikan kesempatan untuk menyampaikan ide/ gagasan dan memikirkan materi yang sedang dipelajari dan bertukar pikiran dengan siswa lain sebelum ide mereka dikemukakan di depan kelas. Hal ini sejalan dengan apa yang kemukakan oleh Lie (2005), bahwa model pembelajaran ini memberi kesempatan sedikitnya delapan kali lebih banyak kepada setiap siswa untuk dikenali dan menunjukkan partisipasi mereka kepada orang lain dari pada model klasikal yang memungkinkan hanya satu siswa yang maju dan membagikan hasil diskusi di depan kelas. Keberadaan fase pemberian tongkat dalam model pembelajaran kooperatif talking stick sangat berpengaruh besar tehadap pemahaman dan penguasaan awal mahasiswa terhadap materi yang dipelajari dan tentunya akan berpengaruh besar terhadap hasil belajar mahasiswa. Hal ini didukung oleh Keller dalam Abdurrahman (2007), yang menyatakan bahwa salah satu faktor yang mempengaruhi hasil belajar mahasiswa adalah faktor yang berasal dari dalam diri mahasiswa, yakni faktor intelegensi dan penguasaan awal mahasiswa.

Adanya kesempatan yang diberikan kepada mahasiswa untuk memikirkan materi/permasalahan yang diberikan oleh dosen akan membangun pemahaman/penguasaan awal mahasiswa terhadap materi yang akan dibahas. Selanjutnya mendiskusikan materi/permasalahan yang telah difkirkan sebelumnya, hal ini memungkinkan mahasiswa untuk menyamakan 
persepsi/jawaban yang sebelumnya telah difikirkan, saling melengkapi, dan saling bekerja sama dengan baik dan efektif dalam merumuskan jawaban dari materi/permasalan yang diberikan oleh dosen, sehingga akan melahirkan suatu jawaban yang betul-betul sesuai dengan apa yang diinginkan. Dalam fase Hal ini dapat dilihat dari data persentase life skill dan hasil belajar mahasiswa, yakni 48 (80\%) mahasiswa yang berada pada kategori sangat baik dan 12 (20\%) siswa yang berada pada kategori baik dan tidak ada mahasiswa yang berada pada kategori cukup, kurang, dan gagal dengan standar deviasi 3.92 .

Tabel 1. Distribusi nilai hasil belajar biologi mahasiswa dengan menggunakan model kooperatif Puzzle dan Talking Stick

\begin{tabular}{lcc}
\hline \multicolumn{1}{c}{ Statistik } & $\begin{array}{c}\text { Model kooperatif tipe } \\
\text { Puzzle }\end{array}$ & $\begin{array}{c}\text { Model kooperatif } \\
\text { Talking Stick }\end{array}$ \\
\hline Nilai rata-rata (mean) & 80,5 & 83,66 \\
Standar Deviasi & 4,64 & 3,92 \\
\hline
\end{tabular}

Mahasiswa yang dibelajarkan dengan model kooperatif tipe Puzzle memperlihatkan hasil belajar yang lebih rendah dibandingkan dengan mahasiswa yang dibelajarkan dengan model kooperatif Talking Stick, hal ini dikarenakan pada saat siswa mengerjakan/menjawab materi dalam LKS secara berkelompok, hanya beberapa orang siswa dalam kelompok yang aktif, sedangkan mahasiswa yang lain hanya berharap dan mengandalkan jawaban teman kelompoknya yang lebih pandai tanpa berusaha untuk membantu meyelesaikan LKS secara bersama-sama. Demikian halnya pada saat persentase materi, hanya sebagian mahasiswa dalam kelompok yang aktif. Umumnya mahasiswa yang aktif dalam diskusi kelompok yang tampil dalam persentase di depan kelas, sehingga tingkat pemahaman mereka terhadap materi berbeda dengan teman-teman kelompok meraka yang tidak aktif.

Selain faktor tersebut di atas, faktor lain yang menyebabkan rendahnya nilai hasil belajar mahasiswa yang dibelajarkan dengan model kooperatif puzzle dibandingkan dengan mahasiswa yang dibelajarkan dengan model kooperatif Talking Stick adalah dari segi aktivitas belajar siswa yang lain, misalnya dalam menyimak mencatat topik dan tujuan pembelajaran, menjawab pertanyaan yang diajukan dosen (apersepsi), mendengarkan dan mencatat penjelasan materi oleh dosen, menjawab / bertanya saat dosen menyampaiakan materi, merumuskan kesimpulan materi, mengerjakan kuis dengan benar (tidak menyontek). Dari hasil observasi yang dilakukan oleh observer ditemukan bahwa dari sejumlah variabel aktivitas yang diamati di atas, persentase aktivitas belajar pada mahasiswa yang dibelajarkan dengan model kooperatif Talking Stick lebih tinggi dibandingkan dengan persentase aktivitas siswa yang dibelajarkan dengan model kooperati Puzzle.

Kelemahan lain dari model pembelajaran kooperatif puzzle yang dapat menyebabkan rendahnya hasil belajar yang diperoleh yakni jika ditinjau dari segi sintaksnya yang masih dekat kemiripannya dengan pembelajaran konvensional. Hal ini sejalan dengan apa yang diungkapkan oleh Trianto (2007), mengenai tinjauan tentang model kooperatif puzzle yang menyatakan bahwa pembelajaran kooperatif tipe puzzle merupakan tipe pembelajaran kooperatif yang cukup 
sederhana. Dikatakan demikian karena kegiatan pembelajaran yang dilakukan masih dekat kaitannya dengan pembelajaran konvensional. Hal ini dapat dilihat dari fase-2 dari fase-fase pembelajaran kooperatif tipe puzzle, yakni adanya penyajian informasi atau materi pelajaran. Perbedaan model ini dengan model konvensional terletak pada adanya pemberian penghargaan pada kelompok.

\section{Kesimpulan}

Berdasarkan hasil penelitian yang telah dilakukan, maka dapat disimpulkan bahwa hasil belajar biologi mahasiswa angkatan 2018 kelas B dibelajarkan dengan menggunakan model pembelajaran kooperatif tipe Puzzle pada mata kuliah sistem pernapasan diperoleh 48,33\% mahasiswa dikategorikan baik sekali, 51,67 \% mahasiswa dikategorikan baik, dan 0,00\% mahasiswa untuk kategori cukup, kurang, dan gagal. Sedangkan hasil belajar mahasiswa kelas A Makassar yang dibelajarkan dengan menggunakan model pembelajaran kooperatif Talking Stick diperoleh $80 \%$ mahasiswa dikategorikan sangat baik, $20 \%$ mahasiswa dikategorikan baik, dan $0,00 \%$ mahasiswa untuk kategori cukup, kurang, dan gagal. Berdasarkan perolehan hasil belajar tersebut, maka dapat disimpulkan bahwa ada perbedaan hasil belajar biologi mahasiswa angkatan 2018 kelas A dan B yang dibelajarkan dengan menggunakan model pembelajaran kooperatif Talking Stick dan model pembelajaran kooperatif Puzzle pada konsep sistem pernapasan.

Sehubungan dengan kesimpulan hasil penelitian di atas, maka saran yang dapat dikemukakan oleh peneliti adalah (1) Untuk meningkatkan life skill dan hasil belajar mahasiswa akan materi dalam proses pembelajaran, sebaiknya pendidik memilih dan mengembangkan model pembelajaran yang berpusat pada mahasiswa, serta melihat keterkaitan antara model dan materi yang akan diajarkan, (2) Perlu diadakan penelitian lebih lanjut dengan mengembangkan variabel penelitian, dalam hal ini metode dan media pembelajaran yang berkaitan dengan model pembelajaran kooperatif Talking Stick dan Kooperatif tipe Puzzle.

\section{Referensi}

Abdurrahman, M. 2007. Pendidikan Bagi Anak Berkesulitan Belajar. Rineka Cipta. Jakarta.

Arikunto, S. 2005. Dasar-dasar Evaluasi Pendidikan. Bumi Aksara. Jakarta.

Abdullah, S., \& Abbas, M. (2006). The effect of inquiry-based computer simulation with cooperative learning. Malaysian On Line journal of Instructional Technology. 3(2). 1-16.

Anderson, O.W., \& Krathwohl, D.R. (2001). A Taxonomy for Learning, Teaching, and Assessing (A Revision of Bloom's Taxonomy of Educational Objectives). New York: Addision Wesley Longman, Inc.

Arends, R. I. (2008). Learning to Teaching. Terjemahan oleh Helly P.S. dan Sri Mulyantini S. Yogyakarta: Pustaka Pelajar. 
Bahri, A. 2016. Pembelajaran Kooperatif, Hasil Belajar Kognitif,. Disertasi tidak diterbitkan. Malang: PPs UM.

Lie, A. 2005. Cooperatif Learning "Mempraktekkan Cooperatif Learning di dalam Ruang-ruang Kelas". Gramedia Widiasarana Indonesia. Jakarta.

Riduwan dan Sunarto. 2007. Pengantar Statistika untuk Penelitian Pendidikan, Sosial, Ekonomi, Komunikasi, dan Bisnis. Alfabeta. Bandung.

Trianto. 2007. Model-model Pembelajaran Inovatif Berorientasi talking Stick Konstruktivistik. Prestasi Pustaka Publisher. Surabaya. 